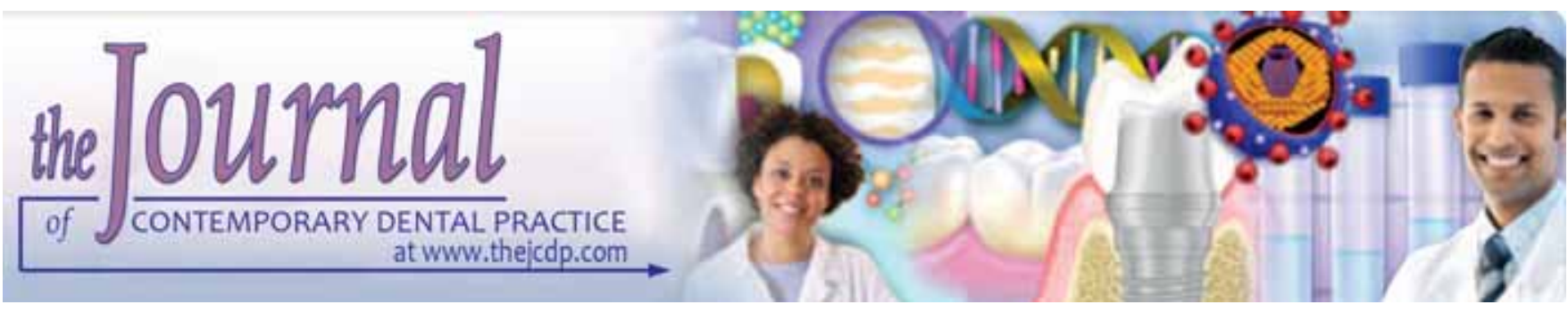

\title{
Retention Strength of Cobalt-Chromium vs Nickel-Chromium Titanium vs CP Titanium in a Cast Framework Association of Removable Partial Overdenture
}

José Everaldo de Aquino Souza, Nelson Renato França Alves da Silva, Paulo Guilherme Coelho, Adriana Cristina Zavanelli Renata Cristina Silveira Rodrigues Ferracioli, Ricardo Alexandre Zavanelli

\begin{abstract}
Aim: There is little information considering the framework association between cast clasps and attachments. The aim of this study was to evaluate the retention strength of frameworks match circumferential clasps and extra resilient attachment cast in three different alloys (cobalt-chromium, nickel-chromium titanium and commercially pure titanium), using two undercut $(0.25$ and $0.75 \mathrm{~mm})$ and considering different period of time $(0,1 / 2,1,2,3,4$ and 5 years $)$.
\end{abstract}

Methods: Using two metallic matrices, representing a partially edentulous mandibular right hemiarch with the first molar crown, canine root and without premolars, 60 frameworks were fabricated. Three groups $(n=20)$ of each metal were cast and each group was divided into two subgroups $(n=10)$, corresponding the molar undercut of $0.25 \mathrm{~mm}$ and $0.75 \mathrm{~mm}$. The nylon male was positioned at the matrix and attached to the acrylic resin of the prosthetic base. The samples were subjected to an insertion and removal test under artificial saliva environment.

Results: The data were analyzed and compared with ANOVAs and Tukey's test at $95 \%$ of probability. The groups cast in cobaltchromium and nickel-chromium-titanium had the highest mean retention strength (5.58 $\mathrm{N}$ and $6.36 \mathrm{~N}$ respectively) without significant difference between them, but statistically different from the group cast in commercially pure titanium, which had the lowest mean retention strength in all the periods $(3.46 \mathrm{~N})$. The association frameworks using nickel-chromium- titanium and cobalt-chromium could be used with $0.25 \mathrm{~mm}$ and 0.75 $\mathrm{mm}$ of undercut, but the titanium samples seems to decrease the retention strength, mainly in the $0.75 \mathrm{~mm}$ undercut. The circumferential clasps cast in commercially pure titanium used in $0.75 \mathrm{~mm}$ undercuts have a potential risk of fractures, especially after the 2nd year of use.

Conclusion: This in vitro study showed that the framework association between cast clasp and an extra resilient attachment are suitable to the three metals evaluated, but strongly suggest extra care with commercially pure titanium in undercut of $0.75 \mathrm{~mm}$.

Clinical significance: Frameworks fabricated in $\mathrm{Cp} \mathrm{Ti} \mathrm{tend} \mathrm{to}$ decrease in retentive strength over time and have a potential risk of fracture in less than $0.75 \mathrm{~mm}$ of undercut.
Keywords: Removable partial denture, Dental clasps, Denture precision attachment.

How to cite this article: Souza JEdA, da Silva NRFA, Coelho PG, Zavanelli AC, Ferracioli RCSR, Zavanelli RA. Retention Strength of Cobalt-Chromium vs Nickel-Chromium Titanium vs $\mathrm{CP}$ Titanium in a Cast Framework Association of Removable Partial Overdenture. J Contemp Dent Pract 2011;12(3):179-186.

Source of support: Nil

Conflict of interest: None declared

\section{INTRODUCTION}

The overdentures are defined as complete or partial removable dentures, which cover roots or osseointegrated implants restoring the dentition. ${ }^{8}$ The maintenance of roots or the use of implant in the removable partial overdentures (RPO) therapy offers several advantages such as less root mobility, better stability and retention, retards bone resorption, the patient can chew better comparable to the conventional complete dentures and leads to a strong psychological value for some patients. ${ }^{3,7}$ The choice of a potential abutment teeth or implant for RPO is based on the prognosis, location in the arch and framework design. ${ }^{25}$ The retention of an RPO is achieved through clasps, adhesive attachments, crowns, and fixed partial dentures (FPD) with intra or extracoronal attachments, telescopes, root caps, and/ or prefabricated intraradicular retainers. ${ }^{16,25}$

Considering the use of intraradicular retainers as the treatment option, the placement of resilient attachment for distal extension for RPO indicated minimal component wear, no radiographic evidence of excessive bone loss, and stable peri-implant soft tissue ${ }^{1,5,6,25}$ and increase patient satisfaction. ${ }^{13}$

Gold type IV and cobalt-chromium (Co-Cr) are among the most frequently used alloys to cast removable partial 
denture (RPD) and RPO frameworks. However, there is still a need to develop a material with ideal properties for fabricating RPD/RPO. The use of titanium (Ti) has then gained popularity. ${ }^{10,12,15,17}$ Characteristics, such as its biocompatibility, corrosion-fatigue resistance, low cost compared with gold alloys and desirable physical and mechanical properties, have contributed to the increased use of commercially pure $\mathrm{Ti}(\mathrm{Cp} \mathrm{Ti})$ and its alloys. ${ }^{9,23,24}$ For mechanical properties stand point, the Ti-based alloys present low modulus of elasticity: 105-120 GPa (http:// en.wikipedia.org/wiki/Young's_modulus). This characteristic allows Ti-based frameworks to be designed using larger retentive undercut areas than recommended for $\mathrm{Co}-\mathrm{Cr}$ alloys, being therefore more advantageous in clinical scenarios where esthetics and/or periodontal health are priorities. ${ }^{2,20}$ Its important to note that with higher retention levels, Cp Ti frameworks may become deformed and fatigued when subjected to repeated stress. ${ }^{20,21}$

Literature is unclear regarding the retentive force generated using undercuts for RPO circumferential clasps as a function of different framework alloys. Lower retentive force values has been shown in previous study ${ }^{19}$ using Tibased circumferential clasp framework located in retentive undercuts of $0.25 \mathrm{~mm}$ and $0.50 \mathrm{~mm}$ when compared to Co$\mathrm{Cr}$ alloys. Contrary to this findings, another report ${ }^{11}$ demonstrated that Ti-Ni alloy clasp might be suitable for removable prosthodontic restorations as a result of significantly lower loss of retention observed than the retention forces recorded for clasps casted in Co-Cr, gold and wire.

Notwithstanding, the data considering the cast framework association between cast circumferential clasp and resilient attachment are scant, and there is no comparison available in the literature considering the interplay of Co-Cr, nickel-chromium-titanium (Ni-Cr-Ti) and $\mathrm{Cp}$ Ti alloys with $0.75 \mathrm{~mm}$ retentive undercut for RPOs.
Considering the scenario of sprouting Ti alloy use for removable frameworks, this study sought to evaluate and compare the retentive strength of resilient attachment on root-clasp association for RPO frameworks using three different alloys (Co-Cr, Cp Ti and Ni-Cr-Ti) and two levels of retentive undercuts subjected to various removalplacement cycles as a function of time. Three research hypothesis were tested:

1. Lower retentive strength is to be expected for Ti-based RPO frameworks as a result of its lower modulus of elasticity.

2. Higher retentive strength is to be expected whenever more retentive undercuts are used for circumferential clasps.

3. The number of removal-placement cycles is inversely proportional to the retentive strength values regardless the framework alloy and retentive undercut used.

\section{MATERIALS AND METHODS}

Two Co-Cr alloy (Star Loy C ${ }^{\circledR}$ Degudent, Dentsply, Petropolis, Brazil) matrices representing a mandibular partially edentulous hemiarch segment with first molar crown and root canine were fabricated with retentive undercuts of $0.25 \mathrm{~mm}$ and $0.75 \mathrm{~mm}$ (Fig. 1A) at the distalcervical-buccal aspect of the molar crown. Guide planes in the mesial and lingual sides of the crown and occlusal-mesial rest seat were also created. The canine root presented a conical format with $10 \mathrm{~mm}$ of length to receive a surveyed Ni-Cr (Fit Cast - SB Plus ${ }^{\circledR}$, Talladium Inc, CA, USA) cast post (ERA System ${ }^{\circledR}$, Sterngold-Implamed, Attleboro, EUA) that was cemented with zinc phosphate cement (Zinc Cement, SS White, Rio de Janeiro, Brazil) (Fig. 1A).

The matrices were positioned in a surveyor, relieved with wax to facilitate the frameworks fabrication, duplicated in silicone (Silicone Master, Talladium Inc, CA, USA) and poured them with the respectively investment. Forty casts
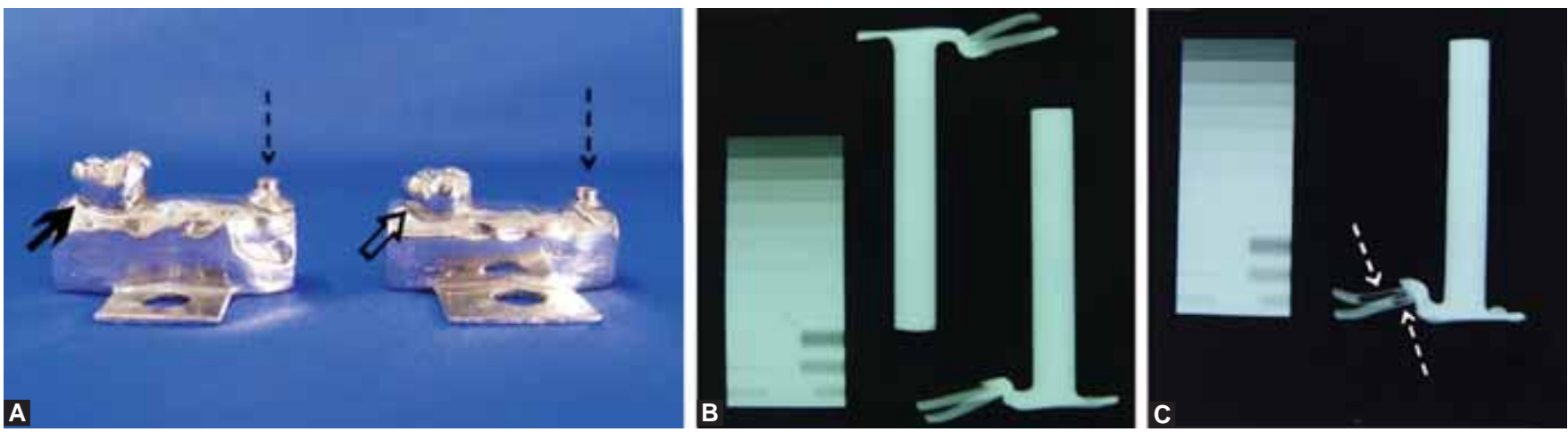

Figs 1 A to $C$ : This figure presents the matrixes (A) with $0.25 \mathrm{~mm}$ (solid black arrow) and $0.75 \mathrm{~mm}$ (opened black arrow) retentive undercuts used for sample preparation. Segmented black arrows point the male component of the attachment duplicated in the matrixes. (B) shows X-ray images of a flawless RPO framework. (C) Segmented white arrows in evidence a flaw present on the clasp of a rejected RPO framework. Note: B and C X-ray reference guide for framework quality evaluation 
Retention Strength of Cobalt-Chromium vs Nickel-Chromium Titanium vs CP Titanium in a Cast Framework Association

\begin{tabular}{|c|c|c|}
\hline Metal alloy manufacturer & Alloy composition (\%) & Investment manufacturer \\
\hline $\begin{array}{l}\text { Co-Cr, Fit Flex }{ }^{\circledR} \text {, Talladium Inc, CA, USA } \\
\text { Ni-Cr-Ti, Vi- Star }{ }^{\circledR} \text {, Talladium Inc, CA, USA } \\
\text { Cp Ti, Realum, São Paulo, Brazil }\end{array}$ & $\begin{array}{l}\text { Co-60; Cr-29; Mo-6.2; } \mathrm{Si}<1 ; \mathrm{Mn}<1 ; \mathrm{C}<1 \\
\mathrm{Ni}-72 ; \mathrm{Cr}-17 ; \mathrm{Mo}-4.5 ; \mathrm{Ti}-6 \\
\mathrm{~N}-0.008 ; \mathrm{C}-0.03 ; \mathrm{H}-0.001 ; \mathrm{Fe}-0.21 \\
\text { O2-0.18; Ti-Bal }\end{array}$ & $\begin{array}{l}\text { Micro Fine } 1700^{\circledR}, \text { Talladium Inc, CA, USA } \\
\text { Micro Fine } 1700^{\circledR} \text {, Talladium Inc, CA, USA } \\
\text { Rematitan Plus }{ }^{\circledR} \text {, Dentaurum, Pforzheim, } \\
\text { Germany }\end{array}$ \\
\hline
\end{tabular}

were obtained using Micro Fine $1700^{\circledR}$ investment (Micro Fine, Talladium Inc, CA, USA) for Co-Cr $(n=20)$ alloy (Fit Flex ${ }^{\circledR}$, Talladium Inc, CA, USA) and Ni-Cr-Ti $(n=20)$ alloy (Vi- Star ${ }^{\circledR}$, Talladium Inc, CA, USA) frameworks. The other twenty casts were obtained utilizing Rematitan Plus ${ }^{\circledR}$ investment (Rematitan Plus, Dentaurum, Pforzheim, Germany) for Cp Ti (Realum, São Paulo, Brazil) framework (Table 1).

Prefabricated wax patterns of the circumferential clasps (Clasps to molar MK, Dentaurum, Pforzheim, Germany) were positioned on the investment casts using a thin layer of adhesive (Wax Fix, Dentaurum, Pforzheim, Germany). Plastic pins $(50 \times 5 \mathrm{~mm})$ were positioned on the retention meshes parallel to the path of insertion using a surveyor to act as sprues for casting the alloys to permit the proper fixation of the samples in the testing apparatus. The casting rings were poured with the same investments used previously in accordance with the manufacturer's instructions.

A total of 60 frameworks were fabricated, ${ }^{18,24}$ distributed into three groups ( $\mathrm{n}=20$ per group of each alloy) and subdivided into two subgroups ( $\mathrm{n}=10$ per subgroup) of 0.25 and $0.75 \mathrm{~mm}$ of undercut to be tested. All specimens were examined radiographically (Figs $1 \mathrm{~B}$ and $\mathrm{C}$ ) for possible casting defects. ${ }^{20,22}$ If any flaw was observed, the specimen was discarded and replaced for a new framework (Fig. 1C).

Sixty prosthetic acrylic (Vipi Flash, VIPI Ind Com, Pirassununga, Brazil) bases were fabricated on prosthetic space of the frameworks to join the resilient components of the ERA $^{\circledR}$ system (ERA System ${ }^{\circledR}$, Sterngold-Implamed, Attleboro, EUA) cemented in the canine roots (Fig. 2A). A black patrix was positioned over the female matrix and captured in the acrylic resin prosthetic base (Pattern Resin, GC Corporation, Tokyo, Japan). The patrix were then switched for gray color patrix to provide adequate retention (Fig. 2B). ${ }^{4,5}$

The frameworks were subjected to a cyclic insertionremoval test performed with 40 cycles/minute at a constant speed of $35.79 \mathrm{~mm} / \mathrm{s}$ in a wet environment at $37 \pm 5^{\circ} \mathrm{C}$ (Cyclic Testing Apparatus, Ribeirao Preto School of Dentistry, São Paulo University) (Figs 2C and D). Total of 5400 cycles
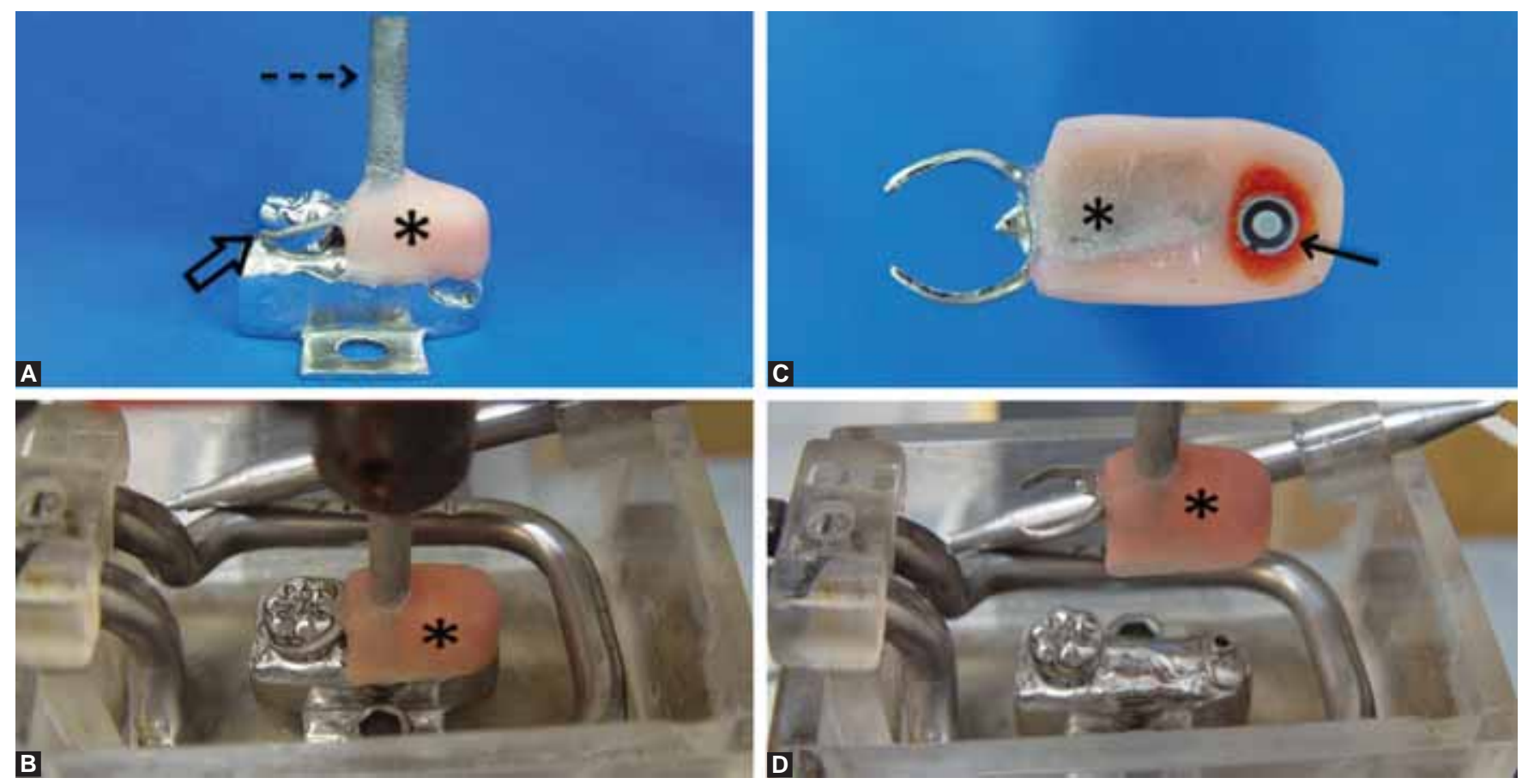

Figs 2A to D: Series of images of sample preparation and test set-up utilized in this investigation. Black asterisks (in all images) lay on the pink acrylic base. Opened black arrow in image (A) points to the tip of the clasp positioned into the retentive undercut. Segmented black arrow evidences metallic rod used for specimen fixation during mechanical testing. Black arrow in (B) demonstrates resilient attachment embedded into the acrylic base, $(C)$ shows the sample placed onto matrix ready to be cyclically placed and removed on the matrix as shown in (D). 
were performed corresponding to 5 years in service. ${ }^{1,12,23,24}$ The retentive strength values were captured at cycle one and after 540, 1080, 2160, 3240, 4320 and 5400 removalplacement testing cycles (corresponding to $1 / 2,1,2,3,4$, and 5 years respectively in service) using data acquisition software (Lab View 8.0, National Instruments, Austin, USA).

The statistical analyses were performed using Two-Way Anova and Tukey's test for group comparisons (SPSS 12.0 software SPSS Inc, Chicago, IL, USA).

\section{RESULTS}

\section{Analyses of the Groups Independent of Retentive Undercuts}

The comparisons between the three groups are presented in the Table 2. Groups Co-Cr and Ni-Cr-Ti showed the highest mean retention strength (5.58 $\mathrm{N}$ and $6.36 \mathrm{~N}$ respectively) with no statistical difference $(\mathrm{p}>0.05)$ between those two. Lowest retention strength (3.46 N) was observed for group Cp Ti ( $<0.05)$ considering all periods evaluated.

\section{Analyses of the Groups Considering all Variables}

The Graph 1 presents the analysis of the retention strength and performance over the time of each design (type of framework alloy as a function of retentive undercut). No statistical difference $(\mathrm{p}>0.05)$ in retentive strength was found between $\mathrm{Co}-\mathrm{Cr}$ and $\mathrm{Ni}-\mathrm{Cr}$-Ti both retentive undercuts subgroups regardless the number of cycles. Cp Ti group with retentive undercut of $0.75 \mathrm{~mm}$ showed lowest retentive strength value $(\mathrm{p}<0.05)$.

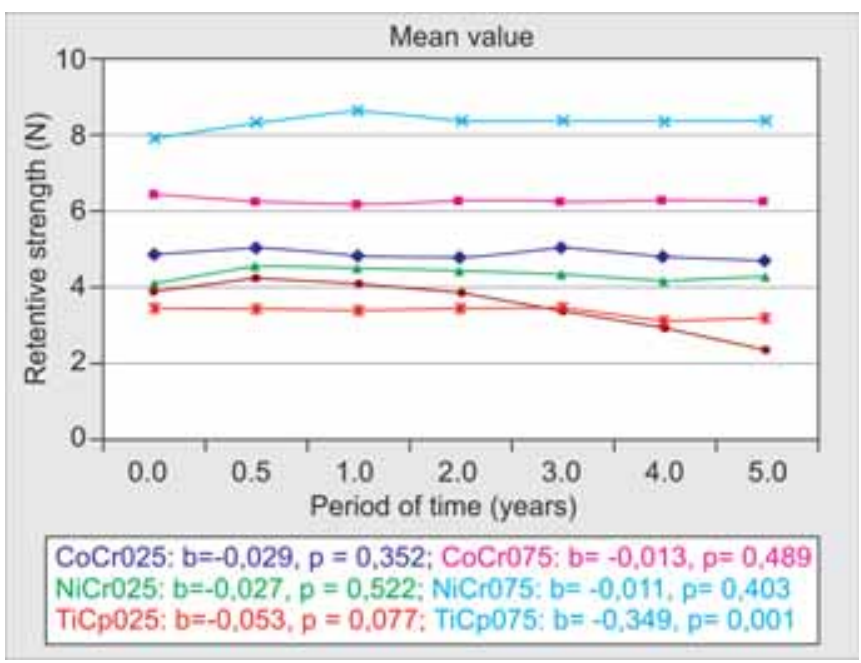

Graph 1: The retention strength in Newton $(\mathrm{N})$ of each group and respective subgroups (undercut of 0.25 and $0.75 \mathrm{~mm}$ ) as a function of time is illustrated. Statistical analyses of group differences are listed with respective $p$-values
Table 2: Mean value and standard deviation of retention strength $(\mathrm{N})$ in each group considering the different period of time analyzed and independent of the undercut level

\begin{tabular}{|c|c|c|c|c|}
\hline \multicolumn{2}{|c|}{ Groups_cycles (period) } & $\begin{array}{l}\text { Mean value } \\
(N)\end{array}$ & $\begin{array}{l}\text { Standard } \\
\text { deviation }\end{array}$ & ${ }^{*} p$-value \\
\hline \multicolumn{5}{|l|}{ Initiation } \\
\hline $\mathrm{Co}-\mathrm{Cr}$ & $A B$ & 5.65 & 2.06 & \\
\hline $\mathrm{Ni}-\mathrm{Cr}-\mathrm{Ti}$ & $A B$ & 6.02 & 2.84 & 0.002 \\
\hline Сp Ti & C & 3.69 & 1.32 & \\
\hline \multicolumn{5}{|c|}{540 cycles (half year) } \\
\hline $\mathrm{Co}-\mathrm{Cr}$ & $A B$ & 5.66 & 1.81 & \\
\hline $\mathrm{Ni}-\mathrm{Cr}-\mathrm{Ti}$ & $A B$ & 6.47 & 3.13 & 0.001 \\
\hline Сp Ti & C & 3.86 & 1.08 & \\
\hline \multicolumn{5}{|c|}{1080 cycles ( 1 year) } \\
\hline $\mathrm{Co}-\mathrm{Cr}$ & A B & 5.52 & 1.88 & \\
\hline $\mathrm{Ni}-\mathrm{Cr}-\mathrm{Ti}$ & $A B$ & 6.59 & 3.32 & 0.001 \\
\hline Сp Ti & C & 3.76 & 0.95 & \\
\hline \multicolumn{5}{|c|}{2160 cycles ( 2 years) } \\
\hline $\mathrm{Co}-\mathrm{Cr}$ & A $B$ & 5.55 & 1.92 & \\
\hline $\mathrm{Ni}-\mathrm{Cr}-\mathrm{Ti}$ & $A B$ & 6.42 & 3.20 & 0.001 \\
\hline Ср Тi & C & 3.66 & 1.01 & \\
\hline \multicolumn{5}{|c|}{3240 cycles (3 years) } \\
\hline $\mathrm{Co}-\mathrm{Cr}$ & A B & 5.67 & 1.96 & \\
\hline $\mathrm{Ni}-\mathrm{Cr}-\mathrm{Ti}$ & $A B$ & 6.39 & 3.22 & $<0.001$ \\
\hline Ср Тi & C & 3.45 & 0.98 & \\
\hline \multicolumn{5}{|c|}{4320 cycles (4 years) } \\
\hline $\mathrm{Co}-\mathrm{Cr}$ & $A B$ & 5.58 & 1.85 & \\
\hline $\mathrm{Ni}-\mathrm{Cr}-\mathrm{Ti}$ & $A B$ & 6.31 & 3.20 & $<0.001$ \\
\hline Сp Ti & C & 3.04 & 1.04 & \\
\hline \multicolumn{5}{|c|}{5400 cycles (5 years) } \\
\hline $\mathrm{Co}-\mathrm{Cr}$ & $A B$ & 5.47 & 1.98 & \\
\hline $\mathrm{Ni}-\mathrm{Cr}-\mathrm{Ti}$ & $A B$ & 6.35 & 3.37 & $<0.001$ \\
\hline $\mathrm{Cp} \mathrm{Ti}$ & C & 2.80 & 1.22 & \\
\hline \multicolumn{2}{|c|}{$\begin{array}{l}\text { Mean-Average total } \\
\text { (considering all periods) }\end{array}$} & $\begin{array}{c}\mathrm{Ni}-\mathrm{Cr}=\mathbf{5 . 5 8} \\
\mathrm{Ni}-\mathrm{Cr}-\mathrm{Ti}=6.36 \\
\mathrm{Cp} \mathrm{Ti}=3.46\end{array}$ & & \\
\hline
\end{tabular}

*Analysis of Variance-ANOVA. Same capital letters in each first column indicate the nonsignificant difference between the designs by Tukey's Test within the same period. The letter A compares the group of $\mathrm{Co}-\mathrm{Cr}$ with the other groups. The letter B compares the group of $\mathrm{Ni}-\mathrm{Cr}$ - $\mathrm{Ti}$ with the other groups. The letter $\mathrm{C}$ compares the group of $\mathrm{Cp} \mathrm{Ti}$ with the other groups

Tables 3 to 5 present the results considering the undercut level analyzed in the different period of time, demonstrating the highest mean value for the Ni-Cr-Ti group (in all periods) and lowest mean value for the Cp Ti group (in all periods), accordingly to the Tukey's test for all pairwise comparisons.

\section{Framework Examination}

The cast frameworks fabricated in $\mathrm{Co}-\mathrm{Cr}$ and $\mathrm{Ni}-\mathrm{Cr}-\mathrm{Ti}$ showed no radiographic defects. For Cp Ti group, seven frameworks (35.0\%) presented radiographically visible porosities and were replaced for flawless framework castings prior testing.

After mechanical testing, five fractured frameworks were identified for group $\mathrm{Cp} \mathrm{Ti}$, being one sample for the retentive undercut of $0.25 \mathrm{~mm}$ (10\% of subgroup failures) and four specimens for retentive undercut of $0.75 \mathrm{~mm}$ (40\% of subgroup failures). No fracture was detected for groups 
Table 3: Mean value of retention strength $(\mathrm{N})$ and standard deviation (SD) in the Co-Cr group considering the different period of time analyzed and the undercut level

\begin{tabular}{|c|c|c|}
\hline $\begin{array}{l}\text { Group-cycles (period)- } \\
\text { undercut level }\end{array}$ & $\begin{array}{l}\text { Mean value }(N) \\
\text { and } S D\end{array}$ & Comparison \\
\hline \multicolumn{3}{|l|}{ Initial period } \\
\hline Co-Cr $0.25 \mathrm{~mm}$ & $4.87-1.92$ & DEFG \\
\hline Co-Cr 0.75 mm & $6.43-1.97$ & ABCDE \\
\hline \multicolumn{3}{|l|}{540 cycles (half year) } \\
\hline Co-Cr 0.25 mm & $5.05-1.91$ & CDEFG \\
\hline Co-Cr 0.75 mm & $6.27-1.53$ & ABCDE \\
\hline \multicolumn{3}{|l|}{1080 cycles (1 year) } \\
\hline Co-Cr 0.25 mm & $4.85-1.79$ & DEFG \\
\hline Co-Cr 0.75 mm & $6.18-1.79$ & ABCDEF \\
\hline \multicolumn{3}{|l|}{2160 cycles ( 2 years) } \\
\hline Co-Cr 0.25 mm & $4.87-1.71$ & DEFG \\
\hline Co-Cr 0.75 mm & $6.31-1.86$ & ABCDE \\
\hline \multicolumn{3}{|l|}{3240 cycles ( 3 years) } \\
\hline Co-Cr 0.25 mm & $5.05-1.90$ & BCDEFG \\
\hline Co-Cr 0.75 mm & $6.27-1.91$ & ABCDE \\
\hline \multicolumn{3}{|l|}{4320 cycles ( 4 years) } \\
\hline Co-Cr 0.25 mm & $4.86-1.74$ & DEFG \\
\hline Co-Cr 0.75 mm & $6.30-1.73$ & ABCDE \\
\hline \multicolumn{3}{|l|}{5400 cycles (5 years) } \\
\hline Co-Cr 0.25 mm & $4.69-1.76$ & DEFG \\
\hline Co-Cr 0.75 mm & $6.25-1.96$ & ABCDEF \\
\hline
\end{tabular}

*Tukey HSD all-pairwise comparison (alpha $=0.05)$. Same capital letters in each third column indicate the nonsignificant difference between the designs by Tukey's Test, considering the numbers of cycles and different period

\begin{tabular}{|c|c|c|}
\hline $\begin{array}{l}\text { Group-cycles (period)- } \\
\text { undercut level }\end{array}$ & $\begin{array}{l}\text { Mean value }(N) \\
\quad \text { and } S D\end{array}$ & Comparison* \\
\hline \multicolumn{3}{|l|}{ Initial period } \\
\hline $\mathrm{Ni}-\mathrm{Cr}-\mathrm{Ti} 0.25 \mathrm{~mm}$ & $4.12-2.53$ & EFG \\
\hline $\mathrm{Ni}-\mathrm{Cr}-\mathrm{Ti} 0.75 \mathrm{~mm}$ & $7.91-1.62$ & $A B C D$ \\
\hline \multicolumn{3}{|l|}{540 cycles (half year) } \\
\hline $\mathrm{Ni}-\mathrm{Cr}-\mathrm{Ti} 0.25 \mathrm{~mm}$ & $4.61-2.97$ & DEFG \\
\hline Ni-Cr-Ti 0.75 mm & $8.31-2.05$ & $A B C$ \\
\hline \multicolumn{3}{|l|}{1080 cycles (1 year) } \\
\hline $\mathrm{Ni}-\mathrm{Cr}$-Ti $0.25 \mathrm{~mm}$ & $4.53-2.98$ & EFG \\
\hline $\mathrm{Ni}-\mathrm{Cr}-\mathrm{Ti} 0.75 \mathrm{~mm}$ & $8.65-2.23$ & A \\
\hline \multicolumn{3}{|l|}{2160 cycles ( 2 years) } \\
\hline $\mathrm{Ni}-\mathrm{Cr}-\mathrm{Ti} 0.25 \mathrm{~mm}$ & $4.47-2.98$ & EFG \\
\hline $\mathrm{Ni}-\mathrm{Cr}-\mathrm{Ti} 0.75 \mathrm{~mm}$ & $8.37-2.08$ & $A B$ \\
\hline \multicolumn{3}{|l|}{3240 cycles (3 years) } \\
\hline Ni-Cr-Ti 0.25 mm & $4.40-2.87$ & EFG \\
\hline $\mathrm{Ni}-\mathrm{Cr}-\mathrm{Ti} 0.75 \mathrm{~mm}$ & $8.38-2.17$ & A \\
\hline \multicolumn{3}{|l|}{4320 cycles (4 years) } \\
\hline $\mathrm{Ni}-\mathrm{Cr}-\mathrm{Ti} 0.25$ mm & $4.20-2.64$ & EFG \\
\hline Ni-Cr-Ti 0.75 mm & $8.40-2.21$ & A \\
\hline \multicolumn{3}{|l|}{5400 cycles (5 years) } \\
\hline Ni-Cr-Ti 0.25 mm & $4.29-3.11$ & EFG \\
\hline Ni-Cr-Ti 0.75 mm & $8.41-2.21$ & A \\
\hline
\end{tabular}

*Tukey HSD all-pairwise comparison (alpha $=0.05$ ). Same capital letters in each third column indicate the nonsignificant difference between the designs by Tukey's Test, considering the numbers of cycles and different period

$\mathrm{Co}-\mathrm{Cr}$ and $\mathrm{Ni}$-Cr-Ti. No damage to gray color patrixes were observed in all groups after cyclic tests.
Table 5: Mean value of retention strength $(\mathrm{N})$ and standard deviation (SD) in the $\mathrm{Cp}$ Ti group considering the different period of time analyzed and the undercut level

\begin{tabular}{|c|c|c|}
\hline $\begin{array}{l}\text { Group_cycles (period)— } \\
\text { undercut level }\end{array}$ & $\begin{array}{l}\text { Mean value }(N) \\
\quad \text { and } S D\end{array}$ & Comparison * \\
\hline \multicolumn{3}{|l|}{ Initial period } \\
\hline Сp Тi 0.25 mm & $3.45-1.01$ & EFG \\
\hline Ср Тi 0.75 mm & $3.93-1.59$ & EFG \\
\hline \multicolumn{3}{|l|}{540 cycles (half year) } \\
\hline Сp Ti 0.25 mm & $3.47-1.00$ & EFG \\
\hline Ср Ti 0.75 mm & $4.24-1.05$ & EFG \\
\hline \multicolumn{3}{|l|}{1080 cycles (1 year) } \\
\hline Ср Тi $0.25 \mathrm{~mm}$ & $3.40-0.82$ & EFG \\
\hline Ср Ti 0.75 mm & $4.12-0.96$ & EFG \\
\hline \multicolumn{3}{|l|}{2160 cycles ( 2 years) } \\
\hline Сp Тi $0.25 \mathrm{~mm}$ & $3.45-1.14$ & EFG \\
\hline Ср Ti 0.75 mm & $3.87-0.86$ & EFG \\
\hline \multicolumn{3}{|l|}{3240 cycles (3 years) } \\
\hline Сp Тi $0.25 \mathrm{~mm}$ & $3.51-1.23$ & EFG \\
\hline Сp Ti 0.75 mm & $3.39-0.70$ & EFG \\
\hline \multicolumn{3}{|l|}{4320 cycles (4 years) } \\
\hline Сp Ti 0.25 mm & $3.14-1.14$ & EFG \\
\hline Сp Ti 0.75 mm & $2.93-0.97$ & FG \\
\hline \multicolumn{3}{|l|}{5400 cycles (5 years) } \\
\hline Сp Ti 0.25 mm & $3.22-1.27$ & EFG \\
\hline Сp Ti 0.75 mm & $2.37-1.04$ & G \\
\hline
\end{tabular}

*Tukey HSD all-pairwise comparison (alpha $=0.05$ ). Same capital letters in each third column indicate the nonsignificant difference between the designs by Tukey's Test, considering the numbers of cycles and different period

\section{DISCUSSION}

Several studies ${ }^{18,19,21,25}$ have tested the use of different alloys in the fabrication of RPD frameworks, mainly evaluating clasp retention with focus related to circumferential or T-bar clasps, however, there are few data considering the association between a cast framework and a resilient attachment, common in clinical situations involving RPO over roots or osseointegrated implant (Mitrani et al, 2003).

This study aimed to verify the performance of an association design between a cast framework with circumferential clasp (cast in three different alloys: Co-Cr, $\mathrm{Ni}-\mathrm{Cr}-\mathrm{Ti}$ and $\mathrm{Cp} \mathrm{Ti}$ ) and a resilient attachment (ERA system, Sterngold-Implamed, Attleboro, USA), simulating five years of RPO clinical service used in different undercuts $(0.25$ and $0.75 \mathrm{~mm}$ ).

Kim and collaborators in $2004^{11}$ performed a study using cyclic test and demonstrated significant decrease in retentive force during repeated cycling for gold and Co-Cr. Exceptions, however, were seen for wrought wire and TiNi based framework, suggesting that Ti-Ni alloy might be suitable for RPD. Despite the different methodology used in Kim's investigation, the results obtained in the present study suggest extra care when $\mathrm{Cp}$ Ti is to be used for RPO. The association involving $\mathrm{Co}-\mathrm{Cr}$ and $\mathrm{Ni}-\mathrm{Cr}-\mathrm{Ti}$ seems to promote a stable retention over the time, suggesting a more 
viable clinical use. However, the $\mathrm{Cp} \mathrm{Ti}$ with $0.75 \mathrm{~mm}$ of retentive undercut showed a decrease of retention strength, particularly after 2160 cycles (equivalent to two years of simulated use).

After the mechanical tests, fractures were found only in the circumferential clasps of the samples casted in $\mathrm{Cp} \mathrm{Ti}$, suggesting technical difficulties in the casting process of Ti alloys. 9,12,14,15,20,23,24 However, the radiographic exam showed no porosity in the fractured buccal arms of Cp Ti $0.75 \mathrm{~mm}$ subgroups, which is in agreement with previous reports. ${ }^{2,12,15,18-22,24}$ Besides, even with the fractures in the retentive arms of the clasps of some samples, retention ranging from $0.81 \mathrm{~N}$ to $2.84 \mathrm{~N}$ after 5,400 cycles was observed as a result of the retention provided by the ERA attachment system. These results are in accordance with studies that reported good retentive performance of the ERA system in clinical service and experimental trials. ${ }^{1,5,6}$

The main difference between the mechanical properties of these metal alloys chosen for this investigation is concerning the modulus of elasticity. $\mathrm{Cp} \mathrm{Ti}$ or $\mathrm{Ti}$ alloys present lower modulus of elasticity and therefore, greater flexibility when compared with Co-Cr and, Ni-Cr alloys. ${ }^{15,21}$ As a result, some authors recommend $\mathrm{Cp} \mathrm{Ti}$ and its related alloys for deep undercut areas for RPD and RPO frameworks. ${ }^{2,11,19}$

Another important aspect that should be pointed is the yield strength, which for Cp Ti is about $400 \mathrm{MPa}$; $572 \mathrm{MPa}$ for Co-Cr alloys; and $690 \mathrm{MPa}$ for Ni-Cr..$^{10,15,17}$ The loss of retention observed for $\mathrm{Cp} \mathrm{Ti}$ with retentive undercut of $0.75 \mathrm{~mm}$ might be related to the low fatigue resistance observed, in which yield strength could be exceeded and caused fractures in $40 \%$ of the samples. Samples that showed no fractures demonstrated a retentive performance similar to the studies cited above. The combination of circumferential clasp with resilient attachment seems have no influence on the retentive performance of the alloys used.

The extension of the denture base with the characteristics of soft tissues, chewing function, periodontal ligament, variability of the path of insertion and removal of patients are factors that can affect the results. ${ }^{6}$ Moreover, the oral environment, composition of saliva and temperature may also interfere with the final findings. ${ }^{1}$ Regarding these limitations, this laboratory study showed valid outcomes compared to those observed in the literature employing clinical conditions such as the utilization of solution of artificial saliva at $37^{\circ} \mathrm{C}$. It is important to note that this investigation analyzed only one retention modality that is the retentive strength obtained by mechanical components. However, in the clinical scenario, other retentive modalities occur such as physiological retention, given the dynamic balance between the prosthetic and paraprosthetic muscle and physical retention, represented by the physical principles of adhesion, cohesion and atmospheric pressure present between the saddle and mucosa. ${ }^{5,6}$ In addition, the amount of force necessary to provide functional retention for a specific patient treated with an overdenture may vary considerably, depending on many factors such as age, strength, muscle and expectations of the patient. ${ }^{6}$

Retention of $5 \mathrm{~N}$ is reported to be adequate for stabilization of RPO and RPD during function. ${ }^{1,11}$ This observation shows that groups $\mathrm{Co}-\mathrm{Cr}$ and $\mathrm{Ni}-\mathrm{Cr}$-Ti presented appropriate mechanical retention required for an RPO. The highest retentive values for the $\mathrm{Ni}-\mathrm{Cr}-\mathrm{Ti}$ alloy can be attributed to a higher modulus of elasticity of the Vi-Star (690 MPa) compared to the modulus of elasticity of the alloy Co-Cr Fit Flex (663 MPa) in accordance with the manufacturer's specifications. The frameworks in Cp Ti showed lower mechanical retention and should be utilized with caution when RPO is the treatment of choice. However, when prosthesis designs involves full arch with multiple circumferential clasps or with more than one attachment, the Cp Ti alloy could provide adequate mechanical retention for the RPO, but this variable was not evaluated in this study.

Horizontal and oblique forces not simulated in this study occur under clinical conditions, such as masticatory forces and parafunction. For this part, may be said that based on this study, movements of insertion and removal of overdentures in a given path can not be the main cause of loss of retention and/or fracture of components corroborating the findings of previous report. ${ }^{1}$

This study was designed to compare cast clasps made to two undercuts: $0.25 \mathrm{~mm}$ and $0.75 \mathrm{~mm}$. The first condition undercut $(0.25 \mathrm{~mm})$ was selected because it represents a common clinical condition and Co-Cr alloy is the material of choice for the manufacture of frameworks for RPD. ${ }^{18,19}$ Today, researchers still seek an ideal material for making up these frameworks. This biomechanical design served, therefore, as a control group in comparison to the other biomechanical designs. Since the initial period up to five years of analysis, the design of Co-Cr in $0.25 \mathrm{~mm}$ undercut showed retention intermediate between the designs, with significant difference only for the design of Ni-Cr-Ti in 0.75 $\mathrm{mm}$ undercut, which had the highest retention among the designs. Thus, there was no significant difference between the metals in the $0.25 \mathrm{~mm}$ undercut. Based on the findings of this study, it could not be verified that there was no significant difference when comparing the design of Co-Cr in $0.25 \mathrm{~mm}$ undercut with the designs of Co-Cr and $\mathrm{Cp} \mathrm{Ti}$ in $0.75 \mathrm{~mm}$ undercut. 
The second condition undercut $(0.75 \mathrm{~mm})$ was included to assess the retention and performance mainly of the frameworks with clasps in $\mathrm{Cp} \mathrm{Ti}$, due to its characteristics of flexibility and resilience. These properties could allow that the retentive arms of the RPD clasps were placed in areas more retentive than is possible with $\mathrm{Co}-\mathrm{Cr}$ and NiCr-Ti. With the increased demand esthetics, the patients claim that the clinical hide RPD clasps putting nearest the gum where the undercuts tend to be more retentive. ${ }^{2}$ However, and contrary to the Bridgeman et al report, ${ }^{2}$ which showed a good performance of $\mathrm{Cp} \mathrm{Ti}$ in this undercut, the results of this study showed a significant loss of retention over time in samples cast with this metal, with fractures in $40 \%$ of the samples. The results showed that the samples in $\mathrm{Ni}-\mathrm{Cr}-\mathrm{Ti}$ and in $\mathrm{Co}-\mathrm{Cr}$ in $0.75 \mathrm{~mm}$ undercuts had a great performance over time with the highest values of retentive force. According to Bridgeman et al (1997), ${ }^{2}$ the rigidity of the Co-Cr clasps make them unsuitable for being placed in $0.75 \mathrm{~mm}$ undercut, because the clasps would cause great tension in the retainers. Additional studies are needed to check the stresses and probable biological reactions of the teeth retainers when used the $\mathrm{Ni}-\mathrm{Cr}-\mathrm{Ti}$ and $\mathrm{Co}-\mathrm{Cr}$ alloys in $0.75 \mathrm{~mm}$ undercuts.

This research sought to collaborate with dentist and prosthodontic in finding the best design according to the metal or metal alloy used in planning in rehabilitation with RPOs. However, future studies using other variables are required and different designs of cast clasps and frameworks, the $0.50 \mathrm{~mm}$ undercuts, different retention degree of the male component of the ERA system and other attachment systems are some examples of variables that need to be explored. The results of this in vitro test should be applied with care and caution. Clinical trials are needed to check the performance of the different biomechanical designs analyzed and the outcomes attained.

\section{CONCLUSION}

Within the limitations of this paper and based on the results of this in vitro study, the retentive strength of the groups cast in $\mathrm{Co}-\mathrm{Cr}$ and $\mathrm{Ni}-\mathrm{Cr}$-Ti showed the highest mean that could be maintained over the time, with no fracture to the clasp. The frameworks fabricated in Cp Ti showed the lowest mean with a remarkable trend to decrease the retentive strength over the time, and under $0.75 \mathrm{~mm}$ of undercut this frames have a potential risk of fracture, especially after the second year of use. Despite the fracture observed in the Cp Ti group in the end of the retentive test, the patrix maintain the retentive strength with no damage and proving efficacy.

\section{REFERENCES}

1. Botega DM, Mesquita MF, Henriques GE, Vaz LG. Retention force and fatigue strength of overdenture attachment systems. J Oral Rehabil 2004; 31(9):884-89.

2. Bridgeman JT, Marker VA, Hummel SK, Benson BW, Pace LL. Comparison of titanium and cobalt-chromium removable partial denture clasps. J Prosthet Dent 1997;78(2):187-93.

3. Brkovic-Popovic S, Stanisic-Sinobad D, Postic SD, Djukanovic D. Radiographic changes in alveolar bone height on overdenture abutments: A longitudinal study. Gerodontology 2008; 25(2):118-223.

4. Chung KH, Chung CY, Cagna DR, Cronin RJ, Jr. Retention characteristics of attachment systems for implant overdentures. J Prosthodont 2004;13(4):221-26.

5. Davidoff SR, Davis RP. The ERA implant-supported overdenture. Compend Contin Educ Dent 1995;16(5): 512,514,516; passim; quiz 522.

6. Epstein DD, Epstein PL, Cohen BI, Pagnillo MK. Comparison of the retentive properties of six prefabricated postoverdenture attachment systems. J Prosthet Dent 1999;82(5):579-84.

7. Fenton AH. The decade of overdentures 1970-1980. J Prosthet Dent 1998;79(1):31-36.

8. Glossary of prosthodontic terms. J Prosthet Dent 2005;94(1):1092.

9. Guilherme AS, Henriques GE, Zavanelli RA, Mesquita MF. Surface roughness and fatigue performance of commercially pure titanium and Ti-6Al-4V alloy after different polishing protocols. J Prosthet Dent 2005; 93(4):378-85.

10. Kelly JR, Rose TC. Nonprecious alloys for use in fixed prosthodontics: A literature review. J Prosthet Dent 1983;49(3):363-70.

11. Kim D, Park C, Yi Y, Cho L. Comparison of cast Ti-Ni alloy clasp retention with conventional removable partial denture clasps. J Prosthet Dent 2004;91(4):374-82.

12. Kononen M, Rintanen J, Waltimo A, Kempainen P. Titanium framework removable partial denture used for patient allergic to other metals: A clinical report and literature review. J Prosthet Dent 1995;73(1):4-7.

13. Mitrani R, Brudvik JS, Phillips KM. Posterior implants for distal extension removable prostheses: A retrospective study. Int J Periodontics Restorative Dent 2003;23(4):353-59.

14. Mori T, Togaya T, Jean-Louis M, Yabugami M. Titanium for removable dentures. I. Laboratory procedures. J Oral Rehabil 1997; 24(5):338-41.

15. Ohkubo C, Hanatani S, Hosoi T. Present status of titanium removable dentures - a review of the literature. J Oral Rehabil 2008;35(9):706-14.

16. Previgliano V, Barone Monfrin S, Santia G, Preti G. Overdentures on natural teeth: A new approach. Minerva Stomatol 2004;53(11-12):631-39.

17. Roach M. Base metal alloys used for dental restorations and implants. Dent Clin North Am 2007;51(3):603-27, vi.

18. Rodrigues RC, Macedo AP, de Torres EM, de Mattos Mda G, Ribeiro RF. Retention force of T-bar clasps for titanium and cobalt-chromium removable partial dentures. Braz Dent J 2008;19(3):209-13.

19. Rodrigues RC, Ribeiro RF, de Mattos Mda G, Bezzon OL. Comparative study of circumferential clasp retention force for titanium and cobalt-chromium removable partial dentures. J Prosthet Dent 2002; 88(3):290-96. 
20. Thomas CJ, Lechner S, Mori T. Titanium for removable dentures. II. Two-year clinical observations. J Oral Rehabil 1997;24(6):414-18.

21. Vallittu PK, Kokkonen M. Deflection fatigue of cobaltchromium, titanium, and gold alloy cast denture clasp. J Prosthet Dent 1995;74(4):412-19.

22. Wang RR, Boyle AM. A simple method for inspection of porosity in titanium castings. J Prosthet Dent 1993;70(3):275-76.

23. Zavanelli RA, Guilherme AS, Pessanha-Henriques GE, de Arruda Nobilo MA, Mesquita MF. Corrosion-fatigue of laser-repaired commercially pure titanium and Ti-6Al-4V alloy under different test environments. J Oral Rehabil 2004;31(10):1029-34.

24. Zavanelli RA, Pessanha Henriques GE, Ferreira I, De Almeida Rollo JM. Corrosion-fatigue life of commercially pure titanium and Ti-6Al-4V alloys in different storage environments. J Prosthet Dent 2000;84(3):274-79.

25. Zitzmann NU, Rohner U, Weiger R, Krastl G. When to choose which retention element to use for removable dental prostheses. Int J Prosthodont 2009;22(2):161-67.

\section{ABOUT THE AUTHORS}

\section{José Everaldo de Aquino Souza}

Postgraduate Student, Department of Prevention and Oral Rehabilitation, FO-UFG, Goiás, Brazil

\section{Nelson Renato França Alves da Silva}

Assistant Professor, Department of Prosthodontics, NYUCD New York, USA

\section{Paulo Guilherme Coelho}

Assistant Professor, Department of Biomaterial and Biomimetics NYUCD, New York, USA

\section{Adriana Cristina Zavanelli}

Assistant Professor, Department of Dental Materials and Prosthodontics, FOA-UNESP, São Paulo, Brazil

\section{Renata Cristina Silveira Rodrigues Ferracioli}

Assistant Professor, Department of Dental Materials and Prosthodontics, FORP-USP, São Paulo, Brazil

\section{Ricardo Alexandre Zavanelli}

Associate Professor, Department of Prevention and Oral Rehabilitation, FO-UFG, Goiás, Brazil

\section{CORRESPONDING AUTHOR}

Ricardo Alexandre Zavanelli, Avenida Dep. Jamel Cecilio, 2496 Jardim Golás 74810-100, Goiânia-Goiás, Brazil, Phone: +5562-30883820 e-mail: ricardozavanelli@hotmail.com 